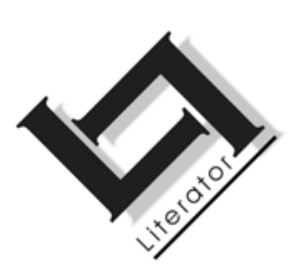

\title{
Woorde wat teken en be-teken - ikonisiteit in die poësie
}

\author{
Heilna du Plooy \\ Skool vir Tale \\ Potchefstroomkampus \\ Noordwes-Universiteit \\ POTCHEFSTROOM \\ E-pos: Heilna.duPlooy@nwu.ac.za
}

\begin{abstract}
Words as signs and signatures - iconicity in poetic texts

In this article aspects of iconicity in language and in poetic texts are discussed. The recent renewed interest in the anti-arbitrary debate is used as a point of departure in order to examine the iconic characteristics and the iconic functions of language and poetic texts. Some less known theoretic views on aspects of iconicity are mentioned and discussed. To underscore the theoretic discussion a few poems of the poet T.T. Cloete are analysed and interpreted focusing on iconicity. The most important conclusions which are once again put forward in the article are firstly that the functioning of poetic texts cannot be adequately described, analysed and interpreted according to logical semantic and linguistic systems alone and that the motivated or iconic origin and archetypical meanings in language can and may indeed play an important role in the production of meaning and secondly that the referential aspect of a text should not be neglected because text analyses of iconic poems once again underscore the view that referentiality indeed remains the basis of the production and communication of meaning.
\end{abstract}

\section{Opsomming}

\section{Woorde wat teken en be-teken - ikonisiteit in die poësie}

In hierdie artikel word verskillende aspekte van ikonisiteit as 'n eienskap van taal en poëtiese tekste ondersoek. Dit word gedoen in die lig van die oplewing in die debat oor die ikoniese aard en funksionering van taal deur te verwys na verskillende teoretiese opvattings oor ikonisiteit. Enkele verse van T.T. 
Cloete word na aanleiding van die ikoniese eienskappe daarin bespreek. Die belangrikste gevolgtrekkings waartoe opnuut in die artikel gekom word, is eerstens dat die funksionering en betekenisgenerering van 'n poëtiese teks nie voldoende op grond van linguistiese of semantiese eienskappe alleen verklaar kan word nie en dat betekenis in 'n gedig ook verband kan hou met die ikoniese of gemotiveerde ontstaan en argetipiese inhoude van taal; en tweedens dat die referensiële aspekte van poëtiese tekste steeds funksioneel bly en in interpretasie verreken moet word, omdat dit in samehang met die spesifieke vorms van ikonisiteit wat in die teks voorkom, die basis van betekenisgenerering en kommunikasie vorm.

\section{Inleiding}

Die vraagstuk van representasie is en was nog altyd een van die kernprobleme van die taal- en literatuurstudie en het sedert die begin van die twintigste eeu net al hoe meer prominent geraak. Die linguis Ferdinand de Saussure se siening van die arbitrêre aard van die verhouding tussen die twee aspekte van die taalteken, tussen die betekenaar en die betekende, het 'n bepalende invloed gehad op die siening van representasie in strukturalistiese, semiotiese en post-strukturalistiese literêre teorieë. Teorieë oor die ikoniese verhouding tussen taaltekens en hulle betekenisse - in die sin dat daar 'n ikoniese of gemotiveerde verhouding tussen taaltekens en betekenis veronderstel word - is met agterdog bejeën en het in die afgelope dekades bykans geen rol in die literêre gesprek gespeel nie. Ikonisiteit in tekste word vanuit die literêre hoek gewoonlik as 'n eienskap van "estetiese" tekste en/of die resultaat van doelbewuste estetiese tegnieke beskou wat 'n verhouding van ooreenkoms tussen die taalkonstruksie en die betekenis daarvan bewerkstellig. Daar is egter wel baie linguiste en taalteoretici wat hulle besig hou met die kwessie van ikonisiteit in taal en kennis van hierdie insigte kan wel die studie van veral die poësie verryk.

In hierdie artikel word eerstens aandag gegee aan die verskynsel van ikonisiteit in taal en in tekste soos wat dit deur spesifieke teoretici gesien word. Dit is nie 'n deurtastende teoretiese bespreking van ikonisiteit nie, maar poog om, in die lig van die herlewing van die anti-arbitrêre debat, enkele fasette van die ikoniese of gemotiveerde aard van taal en van tekste wat vir die lees van poësie nuttig is, uit te lig. Daar word spesifiek na minder bekende teorieë verwys vanweë die interessante moontlikhede wat dit open, al word dié teorieë nie algemeen as gesaghebbend aanvaar nie. Na die teoretiese uiteensetting word spesifieke vorms van ikonisiteit in gedigte van 
T.T. Cloete uitgewys, in besonder sy gebruik van diagrammatiese ikonisiteit waar die gedig as 't ware 'n lyntekening ('n diagram) beskryf, sodat daar van 'n uitgestelde of verplaasde proses van betekenisgenerering gepraat kan word. 1

\section{Ikonisiteit en taal}

In die inleiding van die boek Iconicity in language verwys Raffaele Simone (1994:ix) na die twee teenoormekaarstaande denkpatrone wat van vroeg af ' $n$ bepalende rol in die geskiedenis van die linguistiek gespeel het, naamlik die Platoniese paradigma wat op die ooreenkoms tussen taal en werklikheid berus en die AristoteliesSaussuriaanse paradigma wat die arbitrêre aard van die verhouding tussen taaltekens en die werklikheid as vertrekpunt neem. In die dialoog Kratylus van Plato verduidelik Sokrates sy siening van taal en stel dat klanke, klinkers en medeklinkers, betekenisdraend is en dat so 'n klank sy betekenis oordra op al die woorde waarin hierdie klank gebruik word. Sokrates gee toe dat dit vergesog mag klink, maar voeg by dat dit onvermydelik is.

That objects should be imitated in letters and syllables, and so find expression, may appear ridiculous, Hermogenes, but it cannot be avoided - there is no better principle to which we can look for the truth of first names. (Magnus, 1999:3.)

Binne die arbitrêre taal- en literatuurbeskouings wat in die twintigste eeu met groot sofistikasie ontwikkel en verwoord is, is so 'n standpunt onaanvaarbaar en sal as naïef afgemaak word, maar die manier waarop literêre tekste met ikoniese eienskappe werk en daardeur hulle kompleksiteit vergroot, vereis tog dat 'n mens die saak deegliker bekyk. Simone verwys ook na 'n oplewing in die anti-arbitrêre debat en maak die stelling dat hierdie debat linguiste opnuut daarop attent moet maak "that one has to doubt every kind of linguistics that does not take into account in a sufficiently complex way the problem of how the outside world (participants, settings, actions, etc.) is 'imported' into 'language'” (Simone, 1994:ix).

1 In hierdie artikel word meer aandag aan teorie gegee as aan teksanalise en interpretasie. Die teksbesprekings in die artikel gaan hoofsaaklik om die verskaffing van enkele voorbeelde van ikonisiteit. Die artikel moet liefs saamgelees word met die artikel "Op loop met 'n lyn: T.T.Cloete se toepassings van dante ikonies en intertekstueel gelees" (Du Plooy, 2008) waarin die ikoniese eienskappe van spesifieke gedigte meer uitvoerig ontleed word en waarin die idees van hierdie artikel verder in die teksbesprekings ontgin word. 
Beskou vanuit 'n bepaalde hoek, is die prosesse waardeur werklikheid taal word, presies dit waarmee letterkundiges hulle besig hou. Hulle bestudeer taaltekste waarin die hele spektrum van menslike lewe gerepresenteer word, nie net deur die voorstelling van deelnemers (karakters), ruimtes en handelinge nie, maar ook deur die hantering van abstrakte sake soos idees, gedagtes en emosies. Enersyds is literatuurstudie gerig op die prosesse waardeur lewe en/of "werklikheid", hetsy fiksioneel of "waar", teks word en andersyds word daar ondersoek ingestel na die uitwerking van tekste op lesers. Die bestudering van literêre tegnieke en kunsgrepe, dit wil sê die bestudering van alle manipulasies van taal in estetiese tekste, speel nog altyd 'n bepalende rol in die werk van literatuurwetenskaplikes, selfs al word daar 'n groot verskeidenheid literêr-teoretiese invalshoeke gebruik in die interpretasie van die resultaat van daardie tegnieke.

Die basiese veronderstelling waarop die konsep van ikonisiteit berus, is die moontlikheid dat daar in een of ander vorm 'n (min of meer mimetiese) ooreenkoms sou kon wees tussen taal of 'n teks en die betekenis van die teks. Die ooreenkoms kan verband hou met die vorm, struktuur, klank of ritme van die woorde, die sinne of die teks as geheel. Die logiese vraag sou wees waar hierdie ooreenkoms vandaan kom of waarop dit berus. Sou die ikoniese vermoëns van taal of tekste op 'n inherente eienskap berus sodat gesê kan word dat dit voortkom uit die oorsprong van taal? Is ikonisiteit 'n doelbewuste uitbuiting van 'n bepaalde potensiaal van die taal, teks of tekssoort deur 'n skrywer of digter? Is die ikoniese werkinge van taal bloot 'n lukrake arbitrêre proses?

Vanselfsprekend word die opvattings van ikonisiteit altyd beïnvloed deur die dominante teoretiese beskouing van 'n bepaalde tydperk en daar is verskillende variante definisies van wat dit is en hoe dit in tekste manifesteer, maar die basis van die verskynsel is wel altyd op een of ander manier in die literatuurstudie verreken. ${ }^{2}$

In 'n lesing by 'n internasionale kongres oor ikonisiteit wys Anatoly Liberman (2007b) op die verbasende eienskap van tale dat bepaalde klanke (klinkers, medeklinkers en konsonantgroepe) met bepaalde betekenisse geassosieer kan word selfs oor taalgrense heen:

2 Vir 'n uitvoerige teoretiese ondersoek na die mimetiese eienskappe van taal, vergelyk Müller (1989). 
Onomatopoeia and sound symbolism are important subjects in some works on the origin of language, and it may seem that a leap from the rise of language to the words we use is not particularly hard to make

maar voeg dan dadelik by dat "the emergence of language and the etymology of modern vocabulary cannot, without reservations, be treated as two sides of the same problem" (Liberman, 2007b:15).

In 'n boek Gods of the word - archetypes in the consonants (Magnus, 1999) word gegewens aangaande die verband tussen klank en betekenis ondersoek as manifestasies van die marginale studieterrein van sound symbolism of phonosemantics. Dit gaan nie oor klanknabootsende verhoudings tussen klanke en betekenis as sodanig nie, maar daaroor dat bepaalde klanke opvallend frekwent voorkom in woorde wat semanties verwant is. Magnus (1999:4) gee toe dat "[d]espite the fact that a number of the master linguists of old - Jakobson, Jespersen, Bloomfield, Sapir, Firth - have written beautiful insightful articles on the relationship between sound and meaning, it has never reached the mainstream", maar sê vervolgens van haar ondersoek na die verband tussen klanksekwense en betekenis:

The phenomenon turned out to be astoundingly general. Not only did every group of initial consonants have a very limited set of 'meanings', but the meanings were all interrelated, and each word on average fit into several of them. (Magnus, 1999:4.) ${ }^{3}$

Magnus probeer nie hierdie verskynsel linguisties verklaar nie; trouens sy tree glad nie tot 'n linguistiese debat toe nie. Sy verskaf egter wel 'n groot aantal voorbeelde uit verskillende en uiteenlopende tale en tekensisteme, selfs runeskrif, om haar waarneming te steun (Magnus, 1999:85-111). Haar gevolgtrekking hou wel rekening met die oopeindigheid van betekenisse wat klanke, woorde en taal met verloop van tyd kan ontwikkel, hoewel alle betekenisse volgens haar steeds 'n verband behou met die oorspronklike of "oer"-betekenis:

3 Magnus noem so 'n klanksekwens en sy geassosieerde betekenis 'n phonestheme en gee onder meer die volgende Engelse voorbeelde vir die konsonantkombinasie $/ \mathrm{gl} /$ :

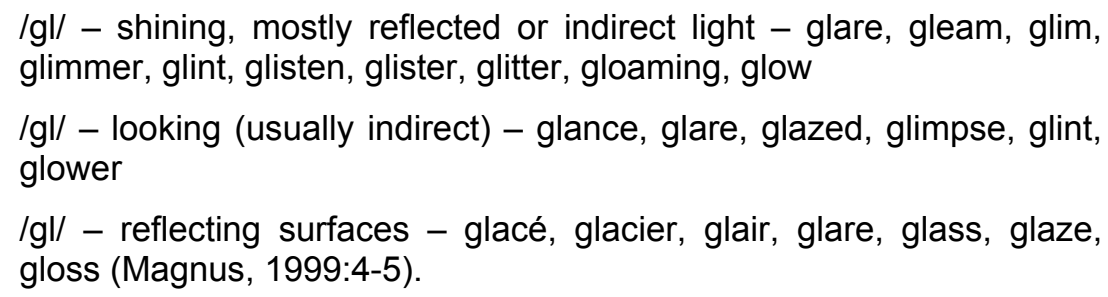


This deeper meaning of a word isn't confined to what we think of as a dictionary definition. Rather it flows out and fills all the space available to it. Although a basic sense does affect the dynamics of a word, it has no power over its essence. Like the captain of a ship, it can control the crew's actions, but not their minds. Each word has an aspect of meaning that lies deeper than any of its senses, and it is fundamentally on this meaning that all the senses depend. (Magnus, 1999:8.)

In sy verwysing na hierdie eienskap van taal verduidelik Liberman (2007a) dat al sou dit wel waar wees dat sekere klanke sekere betekenisse dra of daarmee geassosieer kan word, en al sou dit so wees dat hierdie oerbetekenisse van klanke 'n rol gespeel het in die ontstaan van die betrokke woorde in verskillende tale, die bewys daarvoor so ver in die verskiet lê dat die inligting nie vir 'n linguis van wetenskaplike belang kan wees nie. Dit is immers logies dat kommunikasie so oud soos die mensdom is en hoe spesifieke woorde in 'n taal in oertye ontstaan het, lê so ver in die geskiedenis dat daar geen manier is om iets daarvan op 'n bewysbare manier te herwin nie. Gevolglik werp dit geen lig op vraagstukke waarmee die moderne linguis besig is nie. Liberman (2007a) kom dan tot die eenvoudige en tog uiters insiggewende gevolgtrekking dat taal in sy ontstaan ikonies of gemotiveerd is, maar in sy geskiedenis en ontwikkeling arbitrêr word. Dit is veral waar van die Indo-Europese taalfamilie wat gekenmerk word deur hulle aanpasbaarheid en vermoë om te verander, uit te brei en te ontwikkel.

Die voorbeelde van die klankmatige ontstaan van woorde waarna Liberman en Magnus verwys, sou myns insiens tog kon lei tot bepaalde boeiende vrae. Kan die manier waarop digters met klanke, woorde en betekenisse werk, nie miskien wel in verband gebring word met 'n soort argetipiese kennis of aanvoeling vir die onderliggende vermoëns van taal nie, meer spesifiek met bepaalde subtiele betekenisse en emotiewe eienskappe van die klankwaardes en argetipiese betekenisse van woorde nie? Op die vraag sou daar waarskynlik nie 'n wetenskaplik bewysbare antwoord gegee kon word nie, maar dit is wel iets om in gedagte te hou wanneer bespiegel word oor die kreatiewe vermoëns van mense wat spesifiek in taal na vore kom, soos 'n aanvoeling vir kleur, lyn of vorm by bepaalde visuele kunstenaars op intuïsie of aanvoeling of op die argeologie van kleur berus.

Dit gaan hier allermins om 'n absolute siening van die verband tussen ' $n$ bepaalde klank en 'n bepaalde betekenis, want dit kan verspot maklik weerlê word. Die klankwaarde van byvoorbeeld die fo- 
neem /i/ word dikwels spontaan geassosieer met 'n betekenis van iets wat lig, wit en selfs fyn is, maar woorde soos pik en git wat eerder met pikswart en gitswart geassosieer word, maak die argument oor die klankmatige ligte waarde van die /i/ ongeldig. Nogtans toon Magnus (1999) se naspoor van klankverwante woorde in woordeboeke dat sekere betekenisvelde wel met bepaalde klanke en klankkombinasies geassosieer kan word, dat korrelerende woorde en klanke in verskillende tale voorkom en ook dat daar meer as een semantiese veld vir 'n bepaalde klankkombinasie kan bestaan. Die afleiding kan dus gemaak word dat die klankspel waarmee digters werk en wat ook in volkse taalgebruik en in kinderrympies, aftelrympies en klankimprovisasies voorkom, iets te make sou kon hê met die bewaring van die klankmatig-gemotiveerde oorsprong van taal wat in spontane taaloordrag oor tyd en ruimte heen bewaar gebly het. Tog sal die kontemporêre poësieleser eerder die klankeffekte van 'n gedig op sigwaarde beskou en probeer vasstel wat bepaalde klankpatrone en bepaalde klankteksture en -ritmes tot die betekenis van ' $n$ bepaalde gedig toevoeg. 4

Ook hierin sou Liberman se verduideliking nuttig wees: die klankwaardes in 'n gedig sou in oorsprong (dit wil sê in die oorsprong en ontstaan van die gedig op 'n intuïtiewe vlak) gemotiveer of ikonies kon wees, maar in 'n spesifieke gedig kan die digter so improviserend met klank werk, soveel nuwe patrone maak en die klank op soveel maniere uitbuit dat die potensiële betekenisse van die basiese klankwaardes verander. Verder moet in gedagte gehou word dat 'n gedig deur verskillende lesers in lesings op bepaalde historiese momente telkens totaal anders geïnterpreteer kan word. Die moontlikheid sou dus geopper kon word dat die aanvanklike ikoniese klankmatige struktuur van die gedig wat op aanvoeling berus, in sy verdere ontstaansgeskiedenis (dit wil sê soos wat die digter die gedig bewerk en herbewerk om meerdere betekenisse te ontgin) minder belangrik kan raak of selfs heeltemal onopsigtelik. Ook in die resepsie van die gedig werk soveel eksterne faktore op die verstaan van 'n gedig in dat die aanvanklike betekenisse in latere lesings heeltemal kan verskuif of verplaas kan word.

$4 \quad$ Daar bestaan baie voorbeelde van studies oor die klankpatrone en die gebruik van klank in die poësie. ' $n$ Besonder voortreflike voorbeeld hiervan is ' $n$ boek oor die lerse digter Yeats, Yeats, the master of sound, deur Brian Devine (2006:3), waarin hy met verwysing na vele ander teoretici en kritici, uitvoerig skryf oor nie-semantiese betekenis in Yeats se gedigte, wat onder meer tot stand kom deur die verhouding tussen versreëls en klankpatrone, hetsy harmonieus of nie, en wat aangevoel eerder as verstaan word. 
Ikonisiteit in literêre tekste het egter met veel meer te make as net klank. Die ondersoek na literêre ikonisiteit sluit steeds aan by Peirce (1965:156-173) se bekende onderskeid tussen ikoniese, indeksikale en simboliese tekens (ikone, indekse en simbole) en is gerig op die vermoë van taaltekste om op unieke maniere in 'n ikoniese verhouding tot hulle referente of betekenis te staan. Die voorgaande redenasie oor klank kan ook op ander semantiese aspekte van toepassing gemaak word.

In 'n artikel waarin hy homself ten doel stel om 'n bydrae te maak tot "the doctrine of signs, semiotic in the most basic sense", maak Deely (1994:29) die uitspraak dat ikonisiteit 'n basiese eienskap van alle tekens en tekensisteme is. Volgens Deely is die ikoniese verhouding van 'n teken tot ' $n$ saak onderliggend aan semiose as sodanig: "... removing iconicity in the precise sense to be outlined, there would be no indexical signs or symbols - no signs actually existing as such - anywhere in the universe" (Deely, 1994:29). Hy toon oortuigend aan hoe belangrik dit is dat die funksionering van sowel formele tekens wat slegs in die bewussyn bestaan (daardie tekens wat in 'n abstrakte en arbitrêre verhouding tot sake staan) as die instrumentele tekens (wat gedefinieer kan word as tekens wat betekenis aandui of signifieer op grond van ooreenkoms, gelykenis of analogie) in semiotiese prosesse in ag geneem moet word. In sy siening van ikonisiteit gaan dit juis om die gelyktydige werking van albei soorte verhoudings (Deely, 1994:45).

In die poësie word al die eienskappe van taal op meervoudige maniere uitgebuit om betekenis te kompliseer en te kompakteer, byvoorbeeld deur die aktivering van alle soorte klankpatrone, sintaktiese patrone, semantiese improvisasies asook ritmiese patroonmatighede. Hierdie tegnieke lei daartoe dat die representatiewe vermoë van taal sowel as die vermoë van taal om self as 'n "ding" of "saak" beskou te word, maksimaal op verskillende improviserende maniere benut kan word. 5

Hierby moet in ag geneem word dat by die betekenis van hoogs-gestruktureerde literêre tekste soos gedigte met ikoniese eienskappe, die rol van die kumulerende assosiasies en betekenisse van klanke,

5 Die Nederlandse digter, Marthinus Nijhoff, was van mening dat daar in 'n gedig aanvanklik 'n primêre inhoud is wat soek na 'n bepaalde of geskikte vorm, maar dat die vorm dan 'n tweede inhoud teweegbring sodat die gedig se vorm geen omhulsel is nie, maar die liggaam self, "geen belichaming maar zelf een lichaam" (Nijhoff, 1961:338). 
woorde, taalfrases en -konvensies in die loop van tyd, nie buite rekening gelaat kan word nie. Hierdie eienskap, wat ook beskryf kan word as die argeologie van die taal, is ' $n$ proses waartydens taaltekens voortdurend en deurlopend aangepas word. Hierdie proses geskied omdat betekenis deurlopend en voortdurend gekompliseer en aangepas word na gelang van die gebruik van die taaltekens in bepaalde kontekste en met bepaalde pragmatiese oogmerke. Spore van hierdie gebruiksgeskiedenis word as 't ware in die kollektiewe geheue van die gemeenskap en in die "virtuele argief van die woordgeheue" geberg, sodat die woord sy geskiedenis in homself saamdra - 'n geskiedenis wat in bepaalde gebruike en lesings "opgeroep" kan word en die interpretasie en gebruiksmoontlikhede van woorde en tekste kan beïnvloed (vgl. Cinquin, 1986:179-190).

\section{Vorms van ikonisiteit}

In die kontemporêre gesprek oor ikonisiteit word daar onderskei tussen verskillende soorte ikonisiteit wat in tekste kan voorkom - literêre tekste, ander taaltekste en selfs ander soorte tekentekste soos gebaretaal en verskeie ikonestelsels.

In navolging van Peirce word hoofsaaklik tussen drie soorte ikonisiteit onderskei (Wybenga \& Cloete, 1992:178-181, Nänny, 2001: 209-234), naamlik imaginale, diagrammatiese en metaforiese ikonisiteit, terwyl imaginale ikonisiteit ook soms topologiese ikonisiteit genoem word. Daar is bepaalde digters wie se werk by uitstek ikonies is. Die onderskeid tussen beeldmatige (imaginale) en diagrammatiese ikonisiteit in literêre tekste word byvoorbeeld deur Nänny (2001) uiteengesit in 'n artikel oor die poësie van Cummings omdat Cummings se werk by uitstek hierdie eienskappe vertoon.

Wybenga en Cloete (1992) beskryf die verhouding tussen die teken (representamen in Peirce se terminologie) en die referent (die objek, designatum of denotatum) in imaginale ikonisiteit as " $n$ gelykenis tussen teken en objek wat ruimtelikheid, kontoer of tipografie betref". Nänny (2001:210-213) sluit aan by Roman Jakobson en Peirce en verduidelik dat imaginale (imaginal), beeldmatige of topologiese ikonisiteit akoesties of visueel kan manifesteer. Akoestiese ikonisiteit kom voor in onomatopeïese verskynsels; en visuele ikonisiteit kom voor in visueel opvallende tegnieke soos die gebruik van hoof- en kleinletters, 'n opvallende buitelyn of tipografie in 'n teks of van die teks as geheel, asook gedigte met 'n visueel opvallende tipografiese vorm (vgl. ook Nänny, 1999). 
Diagrammatiese ikonisiteit berus op ikoniese verhoudings tussen die betekenis van tekens en hulle referente en nie op 'n ooreenkoms met die teks as sodanig nie, sodat beweging en verandering ook as voorbeelde van diagrammatiese ikonisiteit beskou kan word (Nänny, 2001:213). Diagrammatiese ikonisiteit kom verder voor waar 'n bepaalde verhouding in die teken analoog is aan dieselfde verhouding in die objek. Wybenga en Cloete (1992:179) gee hier die voorbeeld uit Lord of the flies van William Golding waar die tweeling Sam en Eric met een kollektiewe naam benoem word, naamlik Samneric, omdat hulle in alle opsigte identies is en dus as "een" beskou word. Daar word na metaforiese ikonisiteit verwys wanneer daar 'n parallellistiese verhouding tussen die gedig of deel van 'n gedig en 'n referent tot stand gebring word en wanneer die gelykenis nie tussen die teken en die referent as sodanig voorkom nie, maar tussen twee referente wat metafories deur dieselfde teken aangedui, gedenoteer of geaktiveer word (Wybenga \& Cloete, 1992:180).

By 'n kongres oor ikonisiteit by die Universiteit van Johannesburg in 2007 hou Lars Elleström (2007) in 'n referaat 'n hele stelsel van vorms van ikonisiteit voor; ' $n$ tabel met soveel verskillende moontlikhede dat dit as 'n soort glyskaal beskou kan word. In die tabel word verskillende vorms en grade van intensiteit van sowel imaginale, diagrammatiese en metaforiese ikonisiteit verrreken. Hoewel die stelsel as sodanig te ingewikkeld is en myns insiens nie bruikbaar nie omdat dit bykans onmoontlik gaan wees om 'n bepaalde manifestasie van ikonisiteit so fyn te benoem dat dit met 'n mate van geldigheid op die skema geplaas kan word, illustreer dit wel die groot verskeidenheid moontlike vorms van ikonisiteit in tekste.

In welke vorm ookal het ikonisiteit in 'n literêre teks te make met die komplisering van die verhouding tussen teken of teks en betekenis (hier gaan dit om sowel signifikasie as representasie en interpretasie), sodat betekenis op meerdere maniere gegenereer word en nie net op grond van die semantiese waardes van die woorde en sinne nie. Ikonisiteit word bewerkstellig deur die gebruik van spesifieke kodes, tegnieke of kunsgrepe wat toegevoegde waarde tot die betekenis van die gedig bewerkstellig. Sulke tegnieke kan in onderdele van die gedig werksaam wees, maar ook in die struktuur van die teks as geheel. Vir sommige digters is die struktuur van die 
teks trouens een van die belangrikste vorms van ikonisiteit wat betekenisdraend kan wees. ${ }^{6}$

Daar word algemeen aanvaar dat taal literatuur word deur middel van tegnieke en prosesse van representasie, waardeur referensiële stof getransformeer word tot saamgestelde, gekonsentreerde, veelduidige en meerstemmige betekenis. In 'n literêre teks maak die direkte referensiële betekenis, die logiese en "werklike" of "waar" inligting 'n noodsaaklike maar relatief kleiner komponent uit van die totale betekenis van die teks, aangesien individuele taalelemente in die literêre teks hulle spesifieke betekenis verloor en deel word van die teks as geheel. Roland Barthes (1977:10) noem hierdie eienskap van literêre tekste signifiance om sowel signifikasie as betekenis (meaning) in een term saam te trek. 7 Die literêre teks is uiteindelik 'n

In sy lesings oor Shakespeare maak Coleridge reeds in 1817 die volgende uitspraak: "The organic form ... is innate; it shapes as it develops itself from within, and the fullness of its development is one and the same with the perfection of its outward form" (Lake, 1998:278).

Oor die vraagstuk van die verhouding tussen struktuur en inhoud het Ezra Pound (1954:9) sterk opvattings gehad asook 'n spesifieke voorkeur vir die vryer en meer organiese poëtiese struktuur wat deur modernistiese digters gebruik is: "I think there is a 'fluid' as well as a 'solid' content, that some poems may have form as a tree has form, some as water poured into a vase ... a vast number of subjects cannot be precisely, and therefore nor properly rendered in symmetrical form".

Die noue verband tussen vorm en inhoud is veral deeglik bedink deur Gerard Manley Hopkins wat die term inscape gebruik het vir die innerlike ontwerp of patroon wat 'n objek se kenmerkende vorm bewerkstellig, en die term instress vir die krag wat daardie inscape in stand hou. In 'n insiggewende bespreking van Hopkins se werk in 'n essay toon Lake (1998) aan hoe Hopkins sy terme aan natuurverskynsels ontleen. Op 'n soortgelyke wyse as wat in die natuur die onderliggende struktuur of ontwerp die oppervlakkige struktuur, voorkoms en funksie van 'n objek bepaal, sal 'n gedig se "inscape" sy vorm en betekenis bepaal. Soos baie ander twintigste-eeuse digters en literatore het Hopkins 'n immanente siening van die literêre teks gehuldig en was hy van mening dat poësie 'n bepaalde soort taal is - "speech only employed to carry the inscape of speech for the inscape's sake” (Lake, 1998:301).

$7 \quad$ Signifiance, 'n term van Julia Kristeva, word deur Barthes soos volg gebruik en verduidelik:

Signifiance is a process in the course of which the 'subject' of the text, escaping the logic of the ego-cogito and engaging in other logics (of the signifier, of contradiction), struggles with meaning and is deconstructed ...; signifiance ... [is] ...not the work by which the (intact and exterior) subject might try to master the language ..., but that radical work (leaving nothing intact) through which the subject explores entering not observing - how the language works and undoes him or her (Barthes 1977:10). 
kompleks saamgestelde semiotiese konstruk wat as geheel 'n sogenaamde surplusbetekenis kan dra en waarin struktuur, vorm en betekenis nie geskei kan word nie (Van Gorp et al., 1991:187).

Wat egter nooit buite rekening gelaat moet word nie, is die primêre referensiële funksie van die poëtiese teks. Dit is essensieel dat in sowel die skryf as die lees van poësie hierdie eerste betekenis, die denotatiewe of referensiële aspek, nie in die kompliserende en gekompliseerde poëtiese kommunikasie en interpretasie verlore gaan nie. Dit sou 'n geweldige verlies vir die betekenispotensiaal van die gedig meebring. Daar word juis dikwels gesê dat goeie poësie konkreet is en liefs nie abstrak nie. Daarom sal die eerste laag van betekenis in poëtiese kommunikasie uiters belangrik bly. In die voorbeelde wat later bespreek word, word spesifieke aandag gegee aan die manier waarop die primêre betekenis of aanvanklike referensie in die gedig uitgebuit word.

In sy boek, Lessen in lyriek, beskryf Bronzwaer $(1993: 25,27)$ ikonisiteit deur gebruik te maak van standpunte en uitsprake van Lotman, Hjelmslev en Vestdijk. Volgens Lotman (1972:7-49) is poëtiese taal 'n sekondêre modellerende sisteem wat met die primêre kodes van taal geïntegreer word tot so 'n mate dat dit nie ophefbaar of arbitrêr is nie. Die teks genereer betekenis deur die primêre en die sekondêre modellerende sisteem sowel as deur middel van die interaksie tussen die twee sisteme. Die sekondêre sisteem word nie bloot booor die primêre taalsisteem geskuif nie, maar word 'n inherente en integrale deel van die betekenis van die teks en as sodanig is dit dan ikonies.

Hierdie definisie van poëtiese tekste en poëtiese taal is baie algemeen en sluit uiteindelik bykans alle poëtiese tegnieke en werkwyses in. Bronzwaer (1993:30) praat selfs van sluimerende ikone om besonder subtiele vorms van ikonisiteit aan te dui. Hy analiseer en interpreteer inderdaad ' $n$ wye verskeidenheid ikoniese verskynsels op 'n oortuigende en insiggewende wyse, net soos Wybenga en Cloete (1992) 'n wye verskeidenheid voorbeelde van ikonisitiet bespreek en interpreteer. Hieruit blyk die groot verskeidenheid moontlike vorms van ikonisiteit in die literêre tekste.

\section{Teks en interteks}

Uit bostaande bespreking blyk dat teoretici op sowel die terreine van die literatuurstudie as die linguistiek (en ook digters self), dit almal eens is dat die estetiese teks oor die vermoë beskik om meer betekenis te kan dra as die somtotaal van die referensiële onderdele. 
Ikonisiteit is een van die poëtiese eienskappe waarmee hierdie surplusbetekenis bewerkstellig word, terwyl die primêre referensie as sodanig nooit buite rekening gelaat kan word nie. Die groot verskeidenheid (eintlik 'n oneindige verskeidenheid) manifestasies van vormlike en tekenmatige betekenis noodsaak dat fyner onderskeidings tussen soorte en vorms van ikonisiteit beskryf en benoem word. Hiermee is die proses van betekenisgenerering egter nog nie voldoende omskryf nie.

Die teks as teks en as taal funksioneer nooit in isolasie nie. Selfs 'n ondersoek na ikonisiteit kan nie die intertekstuele werking van taal en tekste buite rekening laat nie; enersyds ten opsigte van die argeologiese inhoud van taal, maar ook ten opsigte van wyer en doelbewus gebruikte intertekstuele en kulturele assosiasienetwerke in en om die teks. In sy boek, Universe of the mind, gebruik Jurij Lotman (2000:20 e.v.) die term outokommunikasie om die werking van die estetiese teks te onderskei van gewone kommunikasie waar die teks daarop gerig is om inligting oor te dra na iemand anders. Normaalweg is kommunikasie daarop gerig om suksesvol, helder en logies inligting van welke aard ook al oor te dra, maar die estetiese teks is volgens Lotman selfgerig, 'n siening wat aansluit by Roman Jakobson (1977:96-107), wat die poëtiese funksie van taal omskryf as die funksie wat die aandag op die teks self vestig. In outokommunikasie is daar drie aspekte wat die totale semantiese waarde van 'n teks beïnvloed. Hierdie drie aspekte kan, vereenvoudig en saamgevat, soos volg beskryf word:

- die primêre semantiese waarde van woorde, wat referensieel is en wat in 'n woordeboek nageslaan kan word;

- die herorganisasie van semantiese elemente wat metafories, sintakties, akoesties of ritmies van aard kan wees;

- die ekstra-tekstuele/buitetekstuele assosiasies wat intertekstualiteit bewerkstellig (Lotman, 2000:29).

Volgens Lotman $(2000: 15-19,153)$ is die uiteindelike eienskap van die estetiese teks dat dit verskillende kodes en kodesisteme meng, teen mekaar afspeel en op mekaar laat inspeel sodat die teks se vermoë om betekenisse te genereer optimaal ontgin word.

Lotman se samevatting van die aspekte wat die betekenisgenerering en dus ook die analise en interpretasie van die poëtiese teks bepaal, verskaf ' $n$ handige raamwerk waarbinne die ikoniese eienskappe van 'n teks in verhouding tot ander betekenisgenererende aspekte verreken kan word. Ikonisiteit is 'n spesifieke vorm van die 
estetiese herorganisasie van talige en semantiese elemente, maar altyd in samehang met die referensiële vermoë van die teks. Dit gaan in literêre tekste nooit net om die referensie of die semantiese as sodanig nie. Dit gaan ook om die referensiële potensiaal van die teks as sodanig, hetsy in sy visuele of akoestiese voorkoms, of in ander meer komplekse implementerings van referensialiteit wat ikonies gelees kan word. Die instrumentele bestaan en betekenis van dinge en abstraksies asook van die teks self, dit wil sê alle vorms van referensie, sowel as die estetiese hantering daarvan en die intertekstuele dimensie wat die argeologiese lading van taal insluit, sal verreken word in die analises wat volg. Daar sal egter deurgaans gepoog word om ook rekenskap te gee van die aanvoeling van die digter en sy poëtiese vermoë om op subtiele wyses te werk met die argetipiese en oorspronklike potensiaal van taal om verborge betekenisse te dra.

\section{Ikoniese gedigte van T.T. Cloete}

Die teksbesprekings in hierdie artikel is nie 'n uitvoerige ontleding van gedigte nie en ook nie 'n verteenwoordigende stel voorbeelde van alle vorms van ikonisitiet nie. Daar word kortliks na drie gedigte as voorbeelde verwys, enersyds om aan te toon dat een digter ' $n$ verskeidenheid ikoniese tegnieke kan gebruik en andersyds as 'n inleiding tot die bespreking van 'n soort "uitgestelde" of "gemedieerde" referensie wat bewerkstellig word deur woorde te gebruik om na ' $n$ visuele vorm te verwys. Die vierde voorbeeld is 'n meer uitvoerige analise en interpretasie van die gedig "Skouspel 1" uit die bundel Jukstaposisie (Cloete, 1982:12) waarin so 'n lyntekening die gedig inlui en as basis vir die verdere verloop van die gedig dien.

In die oeuvre van Cloete kom verskillende vorms van ikonisiteit voor en baie van die gedigte leen hulle by uitstek daartoe om ikonies geanaliseer te word. Trouens, dit is die een eienskap wat in hierdie oeuvre nie nagelaat behoort te word nie. Dit is asof die ikoniese vermoë van taal vir Cloete vanselfsprekend is, iets wat byna nie te ontkom is in die skryf van gedigte nie. Die ikonisiteit manifesteer in verskillende aspekte van die poëtiese taalgebruik, sintakties, klankmatig, tipografies en metafories.

- In die gedig "sweef" in die bundel Jukstaposisie (Cloete, 1982: 47) gebruik die digter slegs een sin om die belewenis van sy plek in die kosmos te beskryf. Die sintaktiese eenheid en samehang is hier ikonies van die holistiese belewenis sowel as die holistiese samehang van die kosmos. Dit kan beskou word as 'n vorm van diagrammatiese ikonisiteit, omdat die sintaktiese eenheid 'n rela- 
sionele ooreenkoms vertoon met die beeld waarin die betekenisinhoud van die vers lê. Daar is ook 'n suggestie van beweging in die beskrywing van die ligstengels wat uitbeweeg vanaf die oog tot by die sterre wat soos klossies aan die buiterand van die disselsaad sit. Dit is egter veral die sintaksis wat hier ikonies van aard is.

snags as van die aarde af uit my oog rondom in die hemel in stengels lig waaierend uitstrek tot die sterre aan hulle punte toe sit ek in die saadkern van 'n onmeetlike disselblom

(Cloete, 1982:47.)

- In "land van die eggo's" in Driepas (Cloete, 1989:119) gaan dit om name wat almal klankmatig iteratief is. Die gedig gaan nie om betekenis as sodanig nie, maar om die spel met klank. 'n Mens sou ook kon bespiegel oor die ontstaan van hierdie klankryke name in die lig van Liberman en Magnus se bevindings oor die gemotiveerde aard van die klanke in woorde. Dit is egter die sensitiewe digtersoor wat die klankmatige rykdom van die name raakhoor en die gedig illustreer of vertoon die klankmatigheid van die name as 'n aspek van taal. Die gedig gaan nie primêr om semantiese waardes nie, maar om die taalspel in gewone en normale taalgebruik, sowel as om die klankmatigheid van taal as sodanig wat ikonies in die gedig gerepresenteer word. Nogtans is die rangskikking van die name nie lukraak nie en veral in die slot is daar duidelik 'n soort klankmatige en ritmiese "tot rus kom", 'n afsluiting wat weereens klankmatig en ritmies bewerkstellig word en nie semanties nie. Slegs die begin en die einde van die gedig word aangehaal.

\section{Land van die eggo's}

Kii Kii

Baobab

Chimanimani

Mojijiji

Boegoe

Bogogobo

Bulbul

Khoekhoen

Dududu

Hella-Hella

Hhelehhele 


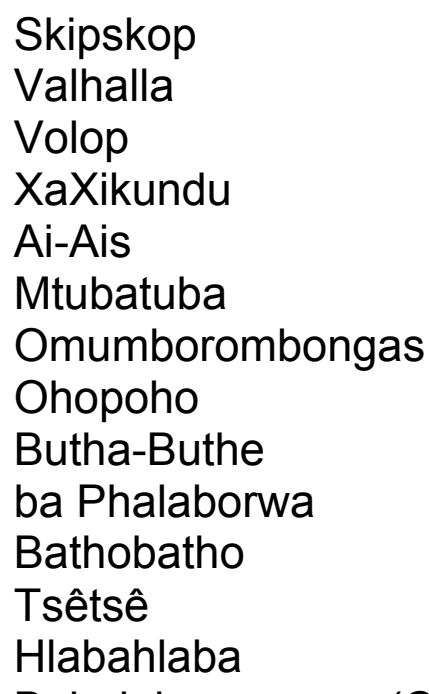

Babalala (Cloete, 1989:119).

In die laaste vyf reëls van die gedig kom die a-klank nege keer voor sodat dit die oorheersense klank is, behalwe in die derde laaste reël waarin die naam Tsêtsê voorkom. Die a-klank, wat hier so sterk vooropgestel word, is in Afrikaans 'n sagte en rustige vokaal en dit bewerkstellig 'n rustiger en traer verloop van die gedig as dit hardop gelees word. Vir my persoonlike taalritmiese aanvoeling dwing die woord Babalala as sodanig ook 'n stadiger praattempo af. Die name in die gedig as geheel kom uit alle tale, maar dit is wel in 'n Afrikaanse bundel opgeneem. Daar kan dus ook verwag word dat by Afrikaanse lesers die Afrikaanse assosiasies van "Babalala", naamlik "baba" en "slaap" opgeroep sal word,8 maar dit is veral die klankassosiasie en die "traer" trant wat deur die baie a-klanke ontstaan wat die gedig tot 'n rustige slot of selfs tot 'n ruspunt bring.

- Wanneer deur Cloete se bundels geblaai word, is dit opvallend dat sy gebruik van tipografie nooit lukraak is nie. As 'n versreël tipografies van die res van die gedig geskei word, is daar 'n duidelike rede voor, wat gewoonlik te make het met die idee dat die apartstaande reël of frase 'n spesifieke funksie het en daarom vooropgestel word. Dit kan soms opposisioneel gelees word en soms gaan dit om semantiese of selfs sintaktiese funksies. In die gedig "jammer" in Uit die hoek van my oog (Cloete, 1998:23) maak die digter 'n inventaris van dinge wat hy gedoen en beleef het, die musiek waarna hy geluister het, die digters wie se werk

8 Baba beteken in Zoeloe pa, maar word ook gebruik as 'n respekvolle aanspreekvorm, terwyl lala in Zulu slaap beteken. In Tswana word lala gebruik vir bly of agterbly maar dit kan ook slaap aandui. Dit gaan egter juis nie om die werklike betekenis van die name nie, maar om die Afrikaanse klankwaardes en assosiasies wat deur die klanke opgeroep word. 
hy gelees het, die skilders wie se werk hy bekyk het en die akademiese werke wat hy kon bestudeer. Hy plaas telkens die klem op die ontroerende uitwerking wat al hierdie kunswerke en studie op hom gehad het. Na 'n lang eerste strofe, kom 'n korter tweede strofe waarvan die laaste reël opgebreek word. Dié reël rym nie met die voorafgaande reëls nie, maar met die eerste reël van die volgende kort strofe. Hierdie kort strofe van drie opvallende kort reëls staan apart en beklemtoon, tipografies maar ook betekenismatig, hoe hierdie mens wat so wyd na alle soorte dinge uitgereik het, nou gereduseer is en in 'n fetusposisie lê. Die aanhaling is vanaf die laaste twee reëls van die tweede strofe:

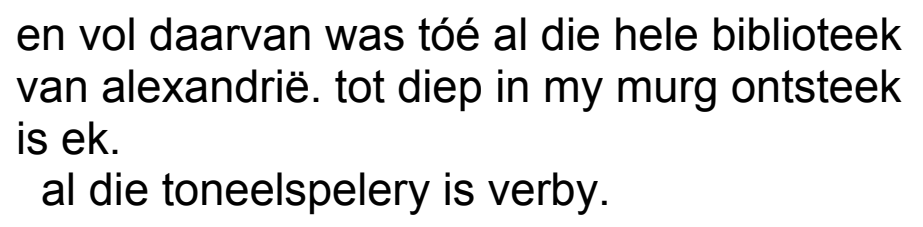

Die sin "tot diep in my murg ontsteek / is ek" is reeds 'n soort skarnier wat 'n oorgang aandui. Daarna volg "al die toneelspelery is verby", wat op grond van die rym aansluit by "op my linkersy", hoewel hierdie reël tot die volgende strofe behoort. Die kort strofe bevat semanties 'n beskrywing van die gereduseerde fisiese toestand van die digter wat vooruit aangedui is deur die frase "tot diep in my murg ontsteek". Die kort reëls stel visueel die reduksie, die vermindering van weerstand, die kleinheid en broosheid voor.

Daarna volg die laaste strofe van die gedig:

so, van my vooroorgevalle kranige kruin af deur my nek

en geboë skouers en rug tot by die hak geteken

soos 'n fetus het 'n vraagteken

met my afgereken.

(Cloete, 1998:23.)

In hierdie strofe word die reduksie van die ek-spreker beskryf in al korter-wordende reëls om weereens die reduksie visueel voor te stel, dus 'n gebruik van imaginale ikonisiteit. Inhoudelik of semanties word gesuggereer dat wat die digter is en wat van hom moet word, ' $n$ vraag is: wat die sin en waarde en toekoms van alles is, is nou 'n vraag en die vraag word nie as vraag gestel nie, maar direk 'n vraag genoem deur te verwys na 'n vraagteken. Meer nog, die woorde beskryf die fetale posisie deur die buitelyn van die geboë liggaam na 
te trek: vanaf die voorkop af oor die geboë skouers en tot by die hak. Die figuur van die digter word "geteken", hy word 'n "teken" wat deur 'n lyn aangedui word. Hierdie lyn vorm egter diagrammaties 'n vraagteken wat in 'n ikoniese verhouding staan tot die "vraagteken" wat met die digter "afreken".

Hierdie artikel het nie ten doel om al die verskyningsvorms van ikonisiteit uitvoerig toe te lig, of alle manifestasies van ikonisiteit in Cloete se oeuvre te beskryf en te benoem nie. Met hierdie inleidende opmerkings word bloot aangedui hoe groot die verskeidenheid en veelvuldigheid ikoniese aspekte is aan die hand van voorbeelde uit die verse van Cloete, en hoe moeiteloos die verse inhoud en vorm gesamentlik poëties funksioneel maak. Vorm en inhoud word inderdaad een. In die volgende afdeling word een gedig uitvoerig bespreek om aan te toon hoe verskillende vorms van ikonisiteit saam en gelyktydig in 'n gedig funksioneer, en hoe die ikoniese vermoëns van taal en van die poësie as genre uitgebuit word.

\section{Diagrammatiese ikonisiteit en 'n skouspel in lyn en vorm}

In die gedig "Skouspel 1" (Cloete, 1982:12) wat vervolgens as 'n ikoniese gedig bespreek word, is die primêre en intermediêre referent 'n lyn, net soos in die gedig "jammer". Die gedigte maak of is "lyntekeninge" omdat lyn in 'n grafiese sin gebruik word om 'n ketting van betekenisgenerering aan die gang te sit - 'n tegniek wat Cloete op verskillende maniere gebruik. ${ }^{9}$

Die idee van 'n vloeiende lyn wat nie net 'n objek teken nie, maar wat as lyn op sigself betekenis dra, word hier deur Cloete effektief ontgin. In "Skouspel 1" word 'n springbok se fynheid en grasie beskryf en daarna hoe die bok deur 'n leeu gevang word. Die beskrywing verwys na 'n springbok wat pronk, wat dus in 'n vertoning van krag en vaart 'n reeks hoë spronge uitvoer, met die vier pootjies netjies bymekaar as hy in die lug is en die stertkwas agteroor getrek sodat dit soos 'n wit pluim op die rug lê. Die leeu se krag word as majesteitlik beskryf en daar word op die skoonheid van die krag van die leeu gewys, asook die "skoonheid" van die wrede skouspel van oorlewing in die natuur. Verskillende vorms en aspekte van skoonheid kom sodoende ironies teenoor mekaar te staan.

$9 \quad$ Vergelyk Du Plooy (2008). 


\section{Skouspel 1}

vanaf die glansende dun horings en die gesig puntig verfynd uit oor die lig geboë rug

tot in die stertkwassie spigtig

gelig af in die glasbreekbaar

dun bene pronk waaierhaar

die springbok nael met die speer

se vaart wip met die haarveer

se spanning hoepel

soepel

onder die leeu majesteitlik veilig

en gevrees pragtig

onder sy gewig

vouknakval

die springbok met 'n klapknal

breek hy die bene en rug en maak prooi

van elegansie wat argeloos mooi

is lê en spartel

voor die gewelddadige mooi wat aanskoulik martel

(Cloete, 1982:12).

Die gedig begin met die beskrywing van 'n lyn wat as 't ware die buitelyn van die bok natrek. Hierdie vorm van ikonisiteit sou as diagrammaties beskryf kon word, omdat dit om 'n mimetiese verhouding gaan tussen die referent, die lyn, en die betekenis, die mooi bok. Daar is egter ook metaforiese ikonisiteit ter sprake, omdat die gedig na sowel die lyn as na die bok verwys en die bok en die lyn in 'n ikoniese verhouding tot mekaar staan. Die referent in die eerste gedeelte van die gedig is inderdaad in die eerste instansie 'n "diagram" wat deur die beskrywing van die lyntekening tot stand kom. Dit is asof die ikonisiteit in twee fases verloop: daar is eers 'n beskrywing wat na 'n lyntekening refereer en die lyntekening stel die buitelyn van 'n springbok voor, dit wil sê die woorde beskryf 'n lyntekening wat na die bok refereer. Wat hierdie aspek van die gedig betref, is daar nie imaginale ikonisiteit in die sin dat die gedig soos die objek/inhoud/betekenis lyk nie, want die gedig "teken" in woorde 'n beeld wat soos die objek lyk. Die gedig beskryf 'n diagram wat verder betekenis genereer. 
Die digter neem letterlik 'n lyn en gaan daarmee "op loop", 10 want die tekening ontstaan en groei in die beskrywing van 'n bewegende lyn. Daar word beskryf hoe die buitelyn van die bok nagetrek sou kon word, wat ook by die dinamiek van die dier in sy vaart en vlugheid aansluit. Dit is egter wel duidelik 'n gekontroleerde en intensionele proses waardeur die grafiese lyn in taal beskryf word: die woorde skep die lyn en die lyn be-"teken" die bok in 'n uitgestelde of verplaaste referensialiteit. Die objek word dus nie metafories in woorde beskryf nie (daar is nie 'n assosiatiewe verhouding nie), maar die woorde refereer na ' $n$ ander mediërende objek, terwyl die beskrywing self reeds die eienskappe van die bok representeer. Die fynheid en grasie van die bok kom ook referensieel en klankmatig in die woorde en klanke na vore: gesig, puntig, lig en spigtig sluit klankmatig bymekaar aan en skep gesamentlik 'n beeld van fynheid wat versterk word deur frases soos "glasbreekbaar dun bene" en "wip met die haarveer se spanning". Die bok is ook "hoepel soepel".

Myns insiens het 'n mens hier te make met 'n intense vorm van vervreemding. Dit gaan om die vooropstelling van die poëtiese tegniek, asook om die verskuiwing van die aandag vanaf die voorwerp of referent na die proses van die beskrywing en na die gedig self. ' $n$ Mens kan dus praat van estetiese prosesse wat in lae oormekaargeskuif word en wat die aandag weg van die saak verskuif na die estetiese representasie van die saak. Wanneer dit by interpretasie kom, moet daar ook gekyk word na die interpretasie van die diere en die uiteindelike vangs, eerder as na die diere en die vangs self.

Die gedig beskik ook oor verdere ikoniese eienskappe daarin dat dit in twee "bewegings" gestruktureer is. In die eerste deel word die bok beskryf en in die tweede die leeu se kragtige aanval. Die beskrywing van die leeu geskied nie in terme van lyn nie, maar in terme van gewig en massa, volume en krag. Die kontras tussen die twee diere en die verhouding tussen hulle word struktureel ikonies uitgebeeld deurdat die aanval, die konfrontasie tussen die diere, in die sentrale gedeelte van die gedig beskryf word. Die bok se ineenstorting word beskryf in 'n tipografies vooropgestelde reël met 'n enkele woord, naamlik vouknakval sodat die gedig letterlik inknak soos wat die bok

10 In die tekenkuns word na aanleiding van 'n uitspraak van Paul Klee (vgl. Frey \& Helfenstein, 2000) dikwels gepraat van "taking a line for a walk". Dit is interessant dat Klee in sy later werk lyn gebruik het as 'n vervreemdingstegniek, om nie net af te beeld of na te teken in figuratiewe sin nie, maar juis om die lyn as 't ware in die ruimte te laat hang, sodat die lyn die aandag verplaas na die artistieke proses in plaas van die referent van die tekening of skildery. 
val en breek onder die leeu. Hierdie reël kan ook beskryf word as 'n vorm van imaginale ikonisiteit, omdat die gedig tipografies (fisies) lyk soos dit wat semanties daar staan.

Die ironie is dat die bok byna "veilig" lyk onder die magtige leeu, maar terselfdertyd "breek" die bok in die aanval. Die ineenstorting word ook onomatopeïes beskryf deur die gebruik van ouditiewe imaginale ikonisiteit in die woorde vouknakval en klapknal waarin die eksplosiewe $k$-klanke die kraakgeluid van die breekslag suggereer. Dit is ook opvallend dat die meegee van die bok met ' $n$ werkwoord gerepresenteer word - dit is 'n handeling, 'n gebeurtenis, 'n belewenis wat 'n dieptepunt is, soos die invou van die gedig ook ikonies illustreer.

Hierdie reël skei én verbind die twee dele van die gedig, waar die eerste deel rondom die bok sentreer en die tweede deel rondom die vangs en die leeu. Daar is dus duidelik 'n ontwikkeling of beweging in die teks en die sentrale kort ingekeepte reël is die skarnier wat die oorgang inlui. Die twee dele van die gedig staan tot mekaar sowel in 'n verhouding van kontras waar dit gaan om die teenstelling tussen die diere, as in 'n verhouding van volgorde. Die volgorde sluit sowel die logiese opeenvolging in die teks in as die semantiese verwysing na die natuurlike proses van lewe en dood in die natuur. Die reël is nie net die dramatiese hoogtepunt van die teks nie, maar die fokus van die gedig, wat in die eerste beweging meer beskrywend is, verskuif hierna ook eksplisiet na interpretasie deur meer bespiegelend oor die betekenis van die vangs te handel.

"Skouspel 1" kom uit die bundel Jukstaposisie (Cloete, 1982) waarin die idee van teenoormekaarstelling of teenoormekaargeplaastheid van verskillende vorms van teenstelling die sentrale tema vorm. Die gedig eindig met die suggestie dat dit om twee teenoormekaarstaande vorms van skoonheid gaan, die fynheid en grasie van spoed en soepelheid van die bok teenoor die majesteitlike en indrukwekkende krag van die leeu. Die gewelddadigheid van die natuur besit dus vir die digter ook skoonheid en die aanskouing van die natuurlike prosesse van die oorlewing van die sterkste is, al is dit ook skrikwekkend, aangrypend. Die ironie is dat die een soort skoonheid die ander vernietig, maar die twee soorte skoonheid word albei as voortreflik voorgestel. Die vernietigende aspek van die jag as sodanig is nogtans indrukwekkend. 


\section{Slot}

Lotman (2000:28) verduidelik die interaksie tussen primêre en sekondêre poëtiese kodes soos volg:

Tension arises between the original message and the secondary code, and the effect of the tension is the tendency to interpret the semantic elements of the text as if they were included in the supplementary syntagmatic construction and have thereby acquired new relationary meanings from this interaction. However, although the secondary code aims to liberate the primary signifying elements from their normal semantic values, this does not happen. The normal semantic values remain but secondary meanings are imposed on them.

Dit is ook insiggewend dat Lotman (2000:28) hieraan toevoeg:

The more the syntagmatic organization is stressed the freer and more associative will be our semantic connections.

In die lig van hierdie uitsprake van Lotman en die teoretiese bespreking in die eerste gedeelte van hierdie artikel, kan die volgende samevattende opmerkings oor die poëtiese werkwyse in "Skouspel 1" gemaak word.

Die ikoniese tegnieke in "Skouspel 1" is onvervreembaar deel van die betekenisgenererende funksie van die gedig. Dit gaan inderdaad om vervreemding en de-outomatisering in 'n ekstreme sin, deurdat die poëtiese tegniek vooropgestel word. Die gedig vestig metatekstueel die aandag op sigself as 'n estetiese objek deur die ontginning van sowel diagrammatiese as imaginale en metaforiese ikonisitiet. Die plasing van woorde en die keuse van woorde ten opsigte van klank en ritme ondersteun die gedagte dat dit gaan om die interpretasie van die skoonheid en geweld, asook die sin van die skoonheid van natuurlike geweld in die natuur. Hier kan ook gedink word aan die term wat Cloete self vir die bou van die gedig gebruik het, naamlik tektoniek waarin 'n mens die woord argitektuur raakhoor. Soos wat 'n gebou se struktuur bepaal wat hy is (Hopkins se "inscape"; Lake, 1998:301), so is dit ook met die gedig. Hierdie gedig word so 'n voorbeeld van 'n vers wat verskillende vorms van ikonisiteit vertoon tot die mate dat die vorm, struktuur, tegniek en betekenis onlosmaaklik ineengestrengel is en saam betekenisgenererend werk. Wat hier uitsonderlik is, is hoe die gebruik van die mediërende lyntekening 'n dubbele referensiële proses as die basis van die betekenis van die gedig gebruik en hoe referensie sowel op 
sigself belangrik is, maar ook tot verdere metaforiese en semantiese assosiasies lei.

As ' $n$ mens die kompleksiteit van die betekenisgenererende prosesse in 'n gedig soos hierdie bekyk, word dit duidelik dat al die tegnieke nie rasioneel "gebruik" word nie. Digterskap lê daarin dat die digter die poëtiese denkwyse en stelwyse beheers deur sowel intellektueel as intuïtief met die moontlikhede van taal om te gaan. Digterskap het waarskynlik veel te make met instress waarvan Hopkins praat, waar die instress die krag of poëtiese vermoë is waaruit die digter put om die inscape én die oppervlakte van die gedig te genereer. Om telkens die klank, woord, vorm of struktuur te kies wat tot veelvuldige koderings en dus veelvuldige en gekompliseerde interpretasies lei, berus op 'n aanvoeling wat verband hou met die onbeskryfbaarheid van poëtiese talent en taalaanvoeling. Hoe onnaspeurbaar en wetenskaplik onbewysbaar dit dan ookal is, poëtiese talent en taalaanvoeling kan nie tot die rasionele en formele linguistiese eienskappe van taal beperk word nie.

\section{Geraadpleegde bronne}

BARTHES, R. 1977. Image - music - text. London: Fontana.

BRONZWAER, W.J.M. 1993. Lessen in lyriek. Nijmegen: SUN.

CINGUIN, C. 1987. The archaeology of the sign. (In Deely, J.N. \& Evans, J.D., eds. Semiotics. London: University Press of America. p. 179-191.)

CLOETE, T.T. 1982. Jukstaposisie. Kaapstad: Tafelberg.

CLOETE, T.T. 1986. Idiolek. Kaapstad: Tafelberg.

CLOETE, T.T. 1989. Driepas. Kaapstad: Tafelberg.

CLOETE, T.T. 1998. Uit die hoek van my oog. Kaapstad: Tafelberg.

CLOETE, T.T. 2001. Die baie ryk ure. Kaapstad: Tafelberg.

DEELY, J. 1986. Idolum: archaeology and ontology of the iconic sign. (In Bouissac, P. \& Herzfeld, M., eds. Iconicity: essays on the nature of culture. Festschrift for Thomas A. Sebeok on his 65th birthday. Tübingen: Stauffenberg Verlag. p. 29-49.)

DEVINE, B. 2006. Yeats, the master of sound: an investigation of the technical and aural achievements of William Butler Yeats. Buckinghamshire: Smythe.

DU PLOOY, H. 2008. Op loop met 'n lyn: T.T.Cloete se transkripsies van dante ikonies en intertekstueel gelees. Literator, 29(3) - nog ter perse.

ELLESTRÖM, L. 2007. Iconicity as meaning miming meaning and meaning miming form. Ongepubliseerde referaat gelewer by die Sesde Simposium oor Ikonisiteit in die Taal en Letterkunde, Universiteit van Johannesburg, 1-4 April 2007.

FREY, S. \& HELFENSTEIN, J., eds. 2000. Paul Klee rediscovered: works from the Bürgi collection. London: Merrel.

JAKOBSON, R. 1977. Linguïstiek en poëtica. (In Bronzwaer, WJ.M., Fokkema, D.W. \& Ibsch, E., reds. Tekstboek algemene literatuurwetenskap. Baarn: Amboboeken. p. 96-106.) 
LAKE, P. 1998. The shape of poetry. (In McDowell. R., ed. Poetry after Modernism. Brownsville: Story Line Press. p. 278-306.)

LIBERMAN, A. 2007a. Iconicity and etymology. Ongepubliseerde referaat gelewer by die Sesde Simposium oor Ikonisiteit in die Taal en Letterkunde, Universiteit van Johannesburg, 1-4 April 2007.

LIBERMAN, A. 2007b. Iconicity and etymology. Programnotas vir Sesde Simposium oor Ikonisiteit in die Taal en Letterkunde, Universiteit van Johannesburg, 1-4 April 2007.

LOTMAN, JU. M. 1972. Die Struktur literarischer Texte. München: Verlag.

LOTMAN, Y.M. 2001. Universe of the mind: a semiotic theory of culture. Translated by Ann Shukman. Bloomington: Indiana University Press.

MAGNUS, M. 1999. Gods of the word: archetypes in the consonants. Kirksville: Thomas Jefferson University Press.

MÜLLER, H.C.T. 1989. Taal en taalmimesis. Johannesburg: Perskor. Sesde Simposium oor Ikonisiteit in die Taal en Letterkunde, Universiteit van Johannesburg, 1-4 April 2007.

NÄNNY, M. 1999. Alphabetical letters as icons in literary texts. (In Nänny, M. \& Fischer, O., eds. Form miming meaning. Amsterdam: Benjamins. p. 173198. (Iconicity in language and literature, 1.))

NÄNNY, M. 2001. Iconic features in E.E. Cummings' poetry. (In Giorcelli, C., ed. The idea and the thing in Modernist poetry. Palermo: Ila Palma. p. 209234.)

NIJHOFF, M. 1961. Verzameld Werk 2 - kritisch, verhalend en nagelaten proza. Amsterdam: Bert Bakker/G.A. van Oorschot.

PEIRCE, C.S. 1965. The icon, index and symbol. (In Hartshorne, C. \& Weis, P., eds. Collected papers of Charles Sanders Peirce. Cambridge: Harvard University Press. p. 156-173.)

POUND, E. 1954. A retrospect. (In Eliot, T.S., ed. Literary essays of Ezra Pound. London: Faber \& Faber. p. 3-14.)

SIMONE, R., ed. 1994. Iconicity in language. Amsterdam: Benjamins. (Current issues in liguistic theory, 110.)

VAN GORP, H., GHESQUIRE, R., DELABATISTA, D. \& FLAMEND, J., reds. 1991. Lexicon van literaire Termen. Groningen: Wolters-Noordhoff.

WYBENGA, G. \& CLOETE, T.T. 1992. Ikoon en ikonisiteit. (In Cloete, T.T., red. Literêre terme en teorieë. Pretoria: HAUM-Literêr. p. 178-182.)

\section{Kernbegrippe:}

ikonisiteit: diagrammaties, imaginaal en metafories

referensialiteit

T.T. Cloete: ikonisiteit in die oeuvre van

vorm en inhoud

vormbetekenis

\section{Key concepts:}

form and content

iconicity: diagrammatic, imaginal and metaphoric

referentiality

T.T. Cloete: iconicity in the oeuvre of

the meaning of form 